\title{
PERANAN sanggar dalam MELestaRikaN KESENIAN TRADISIONAL BETAWI
}

\section{THE ROLE OF STUDIO IN PRESERVING TRADITIONAL CULTURE OF BETAWI}

\author{
Yuzar Purnama \\ Balai Pelestarian Nilai Budaya(BPNB) Bandung \\ Jl. Cinambo No. 136 Ujungberung-Bandung 42094 Tep/Fax. \\ e-mail: yuzarpurnama@gmail.com
}

\begin{abstract}
Abstrak
Indonesia memiliki khasanah budaya yang relatif banyak, salah satunya adalah kesenian tradisional. Kondisi real kesenian tradisional sekarang ini sebagian punah dan sebagian lagi diujung kepunahan (hidup enggan mati tak mau). Upaya pelestarian yaitu perlindungan, pengembangan, dan pemanfaatan sudah dilakukan baik oleh pemerintah maupun masyarakat. Salah satu penyebabnya adalah kurangnya perhatian terhadap wadah/tempat bernaung kesenian, sanggar. Tulisan ini mengupas peran sanggar dalam menjaga kelestarian kesenian tradisional, yang dibatasi pada sanggar yang terdapat di wilayah Betawi, dengan pertimbangan bagaimana kehidupan sanggar kesenian tradisional yang berada di wilayah paling modern di Indonesia. Penelitian bertujuan untuk mendapatkan pengetahuan tentang korelasi sanggar dengan kesenian tradisional. Penelitian ini menggunakan pendekatan kualitatif dengan metode penelitian deskriptif. Penelitian didahului dengan studi pustaka, pengambilan data dengan observasi dan wawancara, dilanjutkan dengan klasifikasi data, analisis data, dan hasil. Kesimpulan penelitian adalah pentingnya eksistensi sanggar sebagai salah satu upaya untuk mengantisipasi kepunahan kesenian khususnya kesenian topeng Betawi, topeng blantek, dan tanjidor. Peranan sanggar dalam kesenian tradisional adalah sebagai wadah/ tempat bernaung sejumlah seni budaya, sebagai media edukasi baik pendidikan maupun latihan, sebagai media hiburan bagi masyarakat sekitar dan peminat seni, sebagai tempat mengatur strategi seputar seni yang ditekuni sebagai tempat bersilaturahmi (berkumpul dan berdiskusi) dalam rangka mempererat persaudaraan.
\end{abstract}

Kata kunci:peranan sanggar, kesenian tradisional, Betawi.

\begin{abstract}
Relatively, Indonesia has many cultural treasures, one of them is a traditional art. Real conditionsof traditional art today partly extinct and partly at the threshold of extinction (reluctant live, but do not want todead). The preservation effort that is the protection, development and utilization has been done either by the government or the public. One reason is the lack of attention to the shelter of art, a studio. This writing examines the role of studios in preserving traditional art, which is restricted to the studio located in the region of Batavia, with consideration of how the life of a traditional art studio located in the most modern in Indonesia. The research aims is to gain the informationrelated to the traditional art studio. This study used a qualitative approach with descriptive research method. Proceeded by doing literature research and collecting data through observation and interviews, followed by data classification, data analysis, and data findings. The results showed that the importance of the existence of the studio as an effort to anticipate the extinction of Betawi art, especially art masks, masks Blantek, and tanjidor. The role of studios in the traditional arts isas a shelter of a number of arts and culture, as a medium of education both education and training, as a medium of entertainment for the local community and art enthusiasts, as a set strategy in the art that occupied as a place to stay in touch (get together and discuss) in order to strengthen the brotherhood.
\end{abstract}

Keywords: Studio roles, traditional cultures, Betawi 


\section{A. PENDAHULUAN}

Kesenian tradisional mulanya menjadi media hiburan dan pendidikan bagi masyarakat pendukungnya. Pada sebagian kesenian tradisional yang tumbuh dan berkembang di Indonesia ada yang memiliki kekuatan magic atau supranatural. Seiring perkembangan zaman dengan masuknya media informasi, lambat laun budaya luar pun masuk ke Indonesia. Berbagai peralatan musik canggih dan kesenian dari luar pun tidak dapat dielakkan ikut menyemarakkan kesenian di Nusantara. Imbasnya keberadaan kesenian tradisional sebagian tersisih dan kehilangan pendukungnya. Namun demikian masih banyak kesenian tradisional yang tetap bertahan dan dapat bersaing dengan kesenian modern.

Salah satu unsur pendukung yang dapat mempertahankan eksistensi kesenian tradisional adalah kepemilikan sanggar. Sanggar mulanya sebagai wadah atau tempat untuk bernaungnya kesenian tradisional. Di tempat ini para pelaku seni berkumpul, berlatih, dan berdiskusi seputar kesenian yang mereka geluti. Sanggar ini pun bisa berfungsi sebagai tempat untuk mempersiapkan dan mengatur strategi.

Sanggar adalah suatu tempat atau sarana yang digunakan oleh suatu komunitas atau sekumpulan orang untuk melakukan suatu kegiatan. Sanggar seni adalah tempat untuk belajar seni seperti seni lukis, seni tari, teater, seni musik, dan kriya/kerajinan ${ }^{1}$.

Selain itu sanggar merupakan salah satu lembaga pelatihan yang termasuk ke dalam jenis pendidikan nonformal. Biasanya sanggar mencakup seluruh proses dari awal hingga akhir yaitu mencakup proses pengenalan (melalui workshop/pelatihan singkat), pembelajaran, penciptaan atau membuat karya, dan produksi. Misalnya pembelajaran melukis, membuat karya lukis kemudian pameran,

${ }^{1}$ (https://id.wikipedia.org/ wiki/Sanggar, diakses tanggal 13 Agustus 2015 pukul 10.10 WIB). penjualan/pelelangan semua dilakukan di dalam sanggar ${ }^{2}$.

Beberapa pelaku kesenian tradisional yang masih eksis pada umumnya memiliki sanggar. Oleh karena itu pada penelitian ini, penulis akan membahas tentang peranaan sanggar pada kesenian tradisional. Penelitian ini dibatasi pada sanggar kesenian tradisional yang berada di wilayah Betawi dan sekitarnya dengan pertimbangan bagaimana kesenian tradisional dapat bertahan pada masyarakat yang modern. Dari sekian banyak sanggar, penulis membatasi menjadi 5 sanggar, yaitu Sanggar Topeng Betawi Cinta Damai, Sanggar Topeng Betawi Setia Warga, Sanggar Topeng Blantek Pangker, Sanggar Topeng Blantek Fajar Ibnu Sena, dan Sanggar Tanjidor (Jikes) Jaip Al-Jabar. Pembatasan sanggar ini dengan pertimbangan kesenian tradisional yang masih ada pada masyarakat Betawi. Dengan kriteria kesenian tradisional yang masih eksis yaitu topeng Betawi, kesenian tradisional yang mulai berkembang yaitu tanjidor (Jikes), dan kesenian tradisional dari kalangan bawah yang hampir punah yaitu topeng blantek.

\section{B. METODE PENELITIAN}

Metode penelitian yang digunakan adalah metode dekriptif, adapun pendekatannya menggunakan pendekatan penelitian kualitatif. Wardi Bachtiar mengatakan bahwa metode deskriptif adalah kegiatan pengumpulan data dengan melukiskannya sebagaimana adanya, tidak diiringi dengan ulasan atau pandangan atau analisis dari penulis (1987:60-61). Data yang dikumpulkan berupa kata-kata, gambar, dan bukan angka-angka. Hal ini diterapkan oleh adanya penerapan metode kualitatif (Maleong, 1989:7). Penggunaan metode kualitatif dipandang sebagai prosedur penelitian yang dapat diharapkan akan menghasilkan data deskriptif, berupa

\footnotetext{
${ }^{2}$ (http://sabilaqueen. blogspot.com/2011/02/peransanggar-seni-dalam-menunjang.html, diakses tanggal 13 Agustus 2015).
} 
kata-kata tertulis atau lisan dari sejumlah orang dan perilaku yang dapat diamati (Taylor dalam Dadang Kahmad, 2000:97).

Langkah-langkah penelitian ini dimulai dengan studi pustaka, dilanjutkan dengan pengumpulan data lapangan dan tertulis dari berbagai media, pemilahan atau klasifikasi data, analisis, dan hasil penelitian.

\section{HASIL DAN BAHASAN}

1. Sanggar Topeng Betawi Cinta Damai

a. Topeng Betawi

Kesenian topeng Betawi hampir sama dengan lenong dan tumbuh di lingkungan masyarakat pinggiran Kota Jakarta. Kesenian topeng Betawi ini terdiri atas topeng blantek dan topeng jantuk. Pertunjukan topeng biasanya dimaksudkan sebagai kritik sosial atau untuk menyampaikan nasihat-nasihat tertentu kepada masyarakat lewat banyolanbanyolan 'guyonan' yang halus dan lucu, agar tidak dirasakan sebagai suatu ejekan atau sindiran ${ }^{3}$.

Topeng Betawi berasal dari kesenian topeng blantek dengan tokohnya bernama Pak Glemon. Kesenian blantek ini memiliki ciri yang sama dengan kesenian topeng Betawi saat ini namun tidak memiliki irama dan lagu-laguan. Dengan demikian kesenian blantek merupakan sebuah lakon yang tidak diiringi dengan musik dan lagu-laguan.

Kesenian tradisional topeng Betawi pertama kali diperkenalkan oleh seorang tokoh yang bernama Ma Kinang. Kesenian ini sudah tumbuh dan berkembang sebelum tahun 1945. Kesenian topeng Betawi pada waktu itu harus mengiblat pada kesenian topeng Betawi yang diperkenalkan oleh Ma Kinang, jika tidak maka tidak akan diakui sebagai kesenian topeng Betawi.

${ }^{3}$ http://www.jakarta.go.id

/web/encyclopedia/detail/3343/Topeng-Be-tawi, diakses tanggal 13 Agustus 2015, pukul 11.00 WIB).

\section{b. Sanggar Topeng Betawi Cinta Damai}

Sebelumnya kesenian topeng Betawi ini tumbuh tidak teratur karena tidak ada lembaga atau instansi yang mengurusi kesenian tradisional ini, namun kini tidak. Hal itu berkat keberadaan lembaga kebudayaan yang selanjutnya mengurusi, mengatur, dan memelihara kesenian tradisional tersebut. Dengan campur tangan lembaga kebudayaan khususnya lembaga kebudayaan yang berada di DKI Jakarta, mereka mulai terdaftar dan diberikan nomor sehingga mereka bisa tampil rutin di Arena Terbuka Perkampungan Budaya Betawi (PBB). Selain itu pemerintah daerah memberikan bantuan dalam bentuk dana kepada sanggar-sanggar yang memenuhi kriteria setelah tentunya diseleksi terlebih dahulu.

Sanggar topeng Betawi berada di pinggiran Jakarta. Sanggar-sanggar ini tidak ada yang menonjol; dalam artian mempunyai fasilitas sanggar yang memadai dan dapat menjadi ajang pagelaran untuk menarik wisatawan nasional maupun internasional.

Jarang ada sanggar yang fokus pada satu kesenian karena pada umumnya dalam sebuah sanggar terdiri atas beberapa kesenian daerah misalnya terdapat kesenian topeng Betawi, pencak silat, dan lenong. Dari sekian sanggar topeng Betawi di antaranya Sanggar Cinta Damai dan Sanggar Setia Warga.

Sanggar Cinta Damai didirikan oleh Amin pada tahun 2000. Sanggar ini beralamat di Jalan Bina Marga RT 06 RW 02 Kecamatan Cipayung. Dengan kepengurusan sebagai berikut: Ketua merangkap sekretaris adalah Amin, Wakil Ketua adalah Azis Sonar, dan Bendahara adalah Milah. Sanggar Cinta Damai berbadan hukum akta notaris kebudayaan. Adapun jumlah personel Sanggar Cinta Damai kurang lebih 25 orang yang terdiri atas pemain musik 10 orang, pemain lakon berjumlah 15 orang, dan cadangan berjumlah 5 orang. Di luar jumlah tersebut ada penari yang berjumlah 7 orang, penari 
ini biasanya diambil dari sanggar lain yang menyediakan personal para penari topeng.

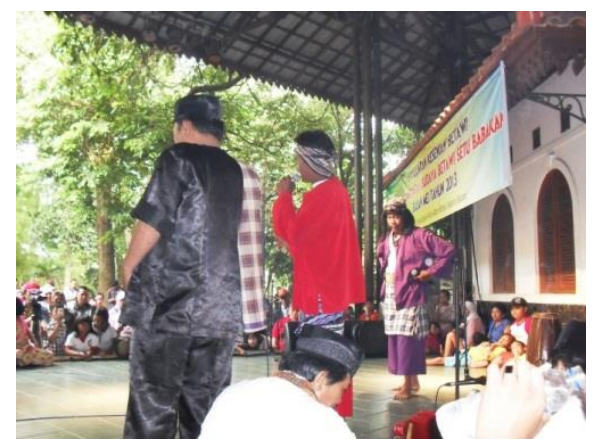

Gambar 1. Grup Kesenian Topeng Betawi Cinta Damai sedang manggung.

Sumber: Dok. BPNB Bandung 2014

Tokoh-tokoh atau maestro kesenian Topeng Betawi di antaranya adalah Pok Nori, Bokir, Mastur, Bolot, dan Sabar. Menurut penuturan Amin, beliau dan teman-temannya mendirikan Sanggar Topeng Betawi Cinta Damai adalah untuk melestarikan kebudayaan Betawi jangan sampai putus, selain itu sebagai mata pencaharian dan tempat mencari nafkah. Namun demikian, menggeluti kesenian tradisional topeng Betawi sebagai sebuah mata pencaharian dalam mencari nafkah untuk kelangsungan keluarga masih jauh dari harapan. Setiap usai mentas para pemain hanya mendapatkan upah sekitar Rp 50.000,- sampai Rp 150.000,-. Pembagian upah ini berbervariasi sesuai dengan beban kerja dan keprofesionalannya. Bagi pemain yang sudah professional seperti Mastur dan Bolot bisa mendapatkan upah sampai $\mathrm{Rp}$ 6.000.000,- sekali tampil. Selain upah bagi para pemain yang relatif kecil juga jam terbang sanggar ini masih kurang karena harus menunggu acara kenduri, sunatan, pernikahan atau acara lain yang jarang, dan persaingan antarsanggar-sanggar yang ada. Oleh karena itu, untuk menyambung hidup para pemain ini mencari pekerjaan sampingan sebagai pedagang, kuli bangunan, tukang ojek, calo tanah, pengrajin, dan sebagainya.

Dalam sanggar Cinta Damai terdapat pemain atau kru yang bukan orang Betawi, yaitu berjumlah 2 orang dari etnis
Sunda. Kedua orang itu bergabung karena menyukai kesenian topeng Betawi. Ada kalanya ketika akan bermain sebuah grup atau sanggar akan meminjam personel dari sanggar lain. Hal ini dianggap wajar dan sudah lumrah. Kasus peminjaman pemain ini disebabkan oleh beberapa alasan yaitu adanya pemain sakit atau adanya pemain yang tidak bisa manggung karena ada halangan. Bisa juga karena di sanggar tersebut tidak ada pemain yang memiliki keahlian seperti itu misalnya penari topeng.

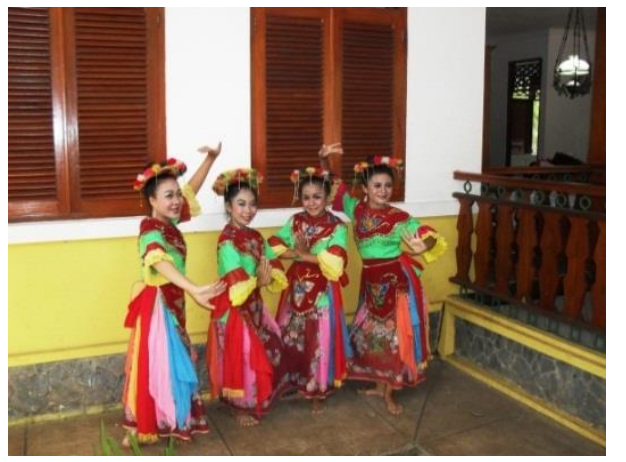

Gambar 2. Penari Topeng Betawi Sumber: Dok. BPNB Bandung 2014

Sanggar Cinta Damai dalam membina dan melatih pemainnya dilakukan rutin oleh seorang pelatih yang bernama Misin. Pak Misin adalah turunan Ma Kinang dari Cibinong. Para pemain topeng Betawi dari Sanggar Cinta Damai adalah Keman, Markim, Lempod, Buang, Napi, Totong, Kimung, Usin, Ajay, Minti, Dewi, Milah, H. Sanan, Tiol, Ani, Mini, dan Mami.

Sejak berdirinya Sanggar Cinta Damai sudah memiliki gedung sendiri yaitu di rumah kediaman Amin. Di gedung ini para pemain berlatih dalam seminggu dua kali yaitu pada malam Kamis dari pukul 22.00 WIB sampai 24.00 WIB dan pada malam Minggu dari pukul 22.00 WIB sampai 24.00 WIB. Gedung ini dilengkapi dengan peralatan gamelan milik sendiri. Rutinitas pemain dalam berlatih dimaksudkan agar para pemain dapat menjiwai apa yang mereka perankan. Selain itu, untuk melestarikan budaya leluhur ini biasanya ketua Sanggar Cinta 
Damai beserta pengurus suka mengajak masyarakat sekitar untuk bergabung dalam kesenian ini. Langkah ini merupakan upaya pengkaderan personel pemain topeng Betawi yang semakin hari semakin surut. Antusiasme masyarakat untuk bergabung dalam grup kesenian ini relatif kurang. Hal itu disebabkan profesi sebagai pemain kesenian tradisional kurang menjanjikan kehidupan masa depan.

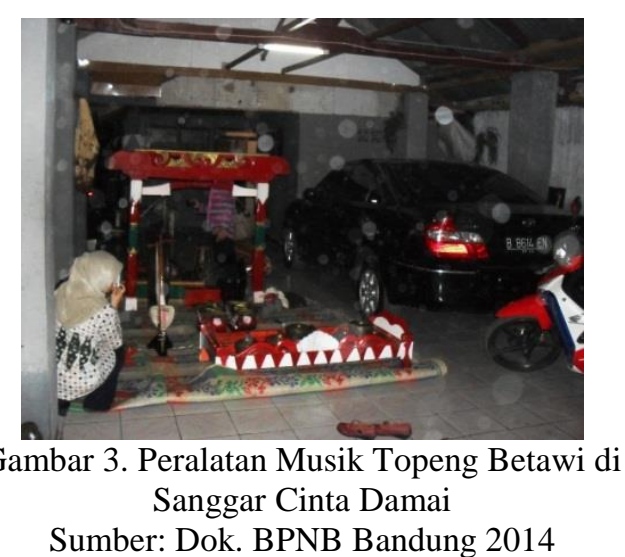

\section{c. Sanggar Topeng Setia Warga}

Sanggar topeng Betawi Setia Warga didirikan pada tahun 1969. Sanggar ini beralamat di Kelurahan Dukuh Kecamatan Kramat Jati Jakarta Timur. Sanggar ini dalam kegiatannya meliputi seni musik dan tari tradisional topeng Betawi. Dengan susunan pengurus sebagai berikut: Ketua Idi Kushandi dan Wakil Ketua Caswana. Adapun personal anggota dibagi tiga jenis yaitu pemain, penari, dan pemusik. Pemusik di Sanggar Topeng Setia Warga adalah Atim memegang gendang, Duriat memegang kenong, Malik Nur Cahyadi memegang kenceng, Deden memegang rebab, Hengki memegang gong, Heri memegang kecrek. Penari di antaranya Kia, penari ini biasanya berjumlah 7 orang. Sementara pemain di antaranya Sabar, Karlin, Edewati, H. Asin, Junaedi, Bejo, Rusli, Engkar, dan Suryati.

Pembinaan intern di sanggar khususnya agar para pemain semakin solid dan profesional dilakukan pelatihan secara rutin. Malam Rabu dan Jumat dipakai untuk latihan musik, malam Rabu dan Sabtu dipakai latihan tarian atau menari, dan malam Selasa dipakai untuk latihan pencak silat. Latihan ini gratis, jika ada masyarakat yang ingin bergabung latihan dipersilakan. Langkah ini dilakukan sebagai upaya untuk mengembangkan budaya daerah sekaligus untuk mencari kader pengkaderan pemain topeng Betawi.

Perjalanan sebagai seniman topeng Betawi dirasakan sangat berat. Salah satunya adalah perjalanan Idi Kushandi sebagai seniman topeng Betawi. Idi Kushandi adalah salah seorang anak dan cucu maestro topeng Betawi, Ma Kinang dan Bokir. Idi Kushandi lahir di Cisalak, sejak kecil sebelum sekolah beliau suka ngamen di Manggarai, Tanjung Priuk, Cilingcing, Pondok Cina, Lenteng Agung, dan Pondok Aren. Ngamen untuk mempertontonkan kesenian topeng Betawi. Setelah sekolah pun terus ngamen. Mereka berjalan dari acara kawinan yang satu ke kawinan yang lainnya atau acara kaulan. Biasanya awal dan akhir ngamen sampai dan sebelum salat Subuh. Cerita yang disuguhkan cukup banyak di antaranya:

1. Pendekar Kucing Hitam, menceriterakan tentang seorang pendekar yang senantiasa membela terhadap kebenaran.

2. Tukang Daun, menceriterakan tentang seorang pedagang daun yang miskin akhirnya menikah dengan orang kaya.

3. Tukang Sate, menceriterakan tentang seorang yang miskin disukai oleh wanita kaya.

4. Si Manis Jembatan Ancol, menceriterakan tentang orang yang dicintai oleh makhluk gaib.

5. Lurah Durja, menceriterakan tentang seorang lurah yang jahat, kejahatannya di antaranya suka mengambil bini (istri) orang lain.

Idi Kushandi, ketua Sanggar Topeng Setia Warga masih keturunan maestro Topeng Betawi yaitu Ma Kinang dan Bokir. Silsilahnya adalah sebagai berikut: Kong Jiun menikah dengan Wa Kimi dikarunia anak yaitu Yumi, Juna Ana, Runah, Nai, dan Bokir. Anak Kong Jiun 
dan Wa Kimi yang bergerak di bidang seni adalah Nai dan Bokir.

Perkawinan Kong Jiun dengan Ma Kinang dikaruniai anak yaitu Kisan, Dali, Limi, Lima, dan Lipah. Anak kong Jiun dengan Ma Kinang yang bergerak di bidang seni adalah Kisam, Dali, dan Lima.

Perkawinan Bokir dengan Hj. Sipon dikaruniai anak yaitu Idi Kushandi dan Endang Sudardi, keduanya seniman.

Pernikahaan Bokir dengan Hj. Tipis dikaruniai anak yaitu Suwari, Sukria (Sabar), dan Sumiyati. Anaknya yang bergerak di bidang seni adalah Sabar sebagai penari dan Sumiyati sebagai penari di Jepang.

Sanggar Setia Warga memiliki jumlah anggota kurang lebih 30 sampai 50 orang. Dalam setiap pertunjukan grup topeng Betawi ini menawarkan harga $\mathrm{Rp}$ $30.000 .000,-$. Selesai pertunjukan, para pemain langsung diberikan honornya oleh ketua atau bendahara. Pemberian honor tidaklah merata melainnya disesuaikan dengan peran dan beban seseorang dalam bermain. Makin berat beban perannya dan makin terkenal orangnya, upahnya pun akan lebih tinggi dibandingkan dengan pemain lainnya.

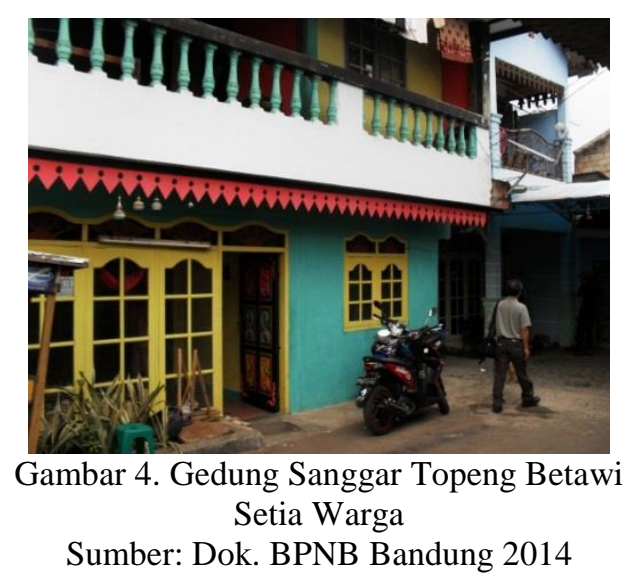

Sanggar Topeng Setia Warga sudah memiliki gedung untuk berlatih sekaligus sekretariatnya. Gedung ini berada di rumah Idi Kushandi. Selain gedung, sanggar ini pun sudah memiliki perangkat gamelan topeng Betawi.

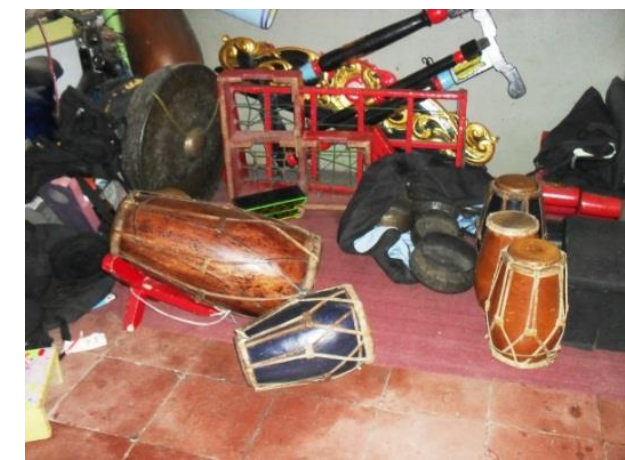

Gambar 5. Peralatan Musik Topeng Betawi di Sanggar Setia Warga

Sumber: Dok. BPNB Bandung 2014

Minimnya masyarakat yang mengundang kesenian topeng Betawi di antaranya karena sudah berkurangnya pelataran untuk pertunjukan, sementara pertunjukan topeng Betawi mengundang penonton cukup banyak. Selain itu, menurut ketua Sanggar Topeng Betawi Setia Warga adalah kurangnya perhatian dari pemerintah dan sampai sekarang Pemerintah Daerah DKI Jakarta belum pernah berkunjung atau bertandang ke Sanggar Topeng Betawi Setia Warga.

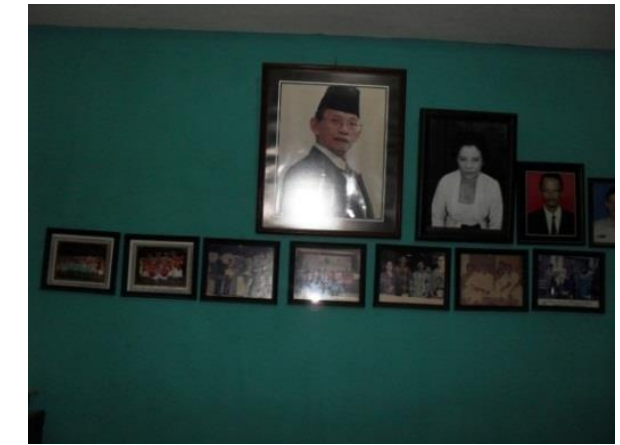

Gambar 6. Foto Bokir Sang Maestro Topeng Betawi Menghiasi Sanggar

Sumber: Dok. BPNB Bandung 2014

\section{SANGGAR TANJIDOR JAIP AL--JABAR}

a. Tanjidor

Tanjidor merupakan kesenian peninggalan bangsa Portugis, yang sering dinikmati tuan tanah Belanda, dan dimainkan untuk mengiringi tamu di kala jamuan makan. Setelah pemerintahan kolonial menyerahkan kekuasaannya kepada Jepang, kesenian tanjidor dilarang 
dipertunjukkan oleh pemerintah Jepang. Setelah Indonesia merdeka, tanjidor mengalami pasang surut (Lasmiyati, 2002:169-170). Pada tahun 1954, ketika walikota dijabat Sudiro, ia memberlakukan pelarangan pertunjukan tanjidor di jalanan, juga tidak diperbolehkan ngamen, terutama pada perayaan tahun baru Cina. Pelarangan tersebut tentu saja telah mengecewakan para senimam tanjidor, karena telah memutus mata pencaharian mereka. Mereka hanya tinggal menunggu tampil jika ada permintaan dari yang mempunyai suatu acara (Setiati, 2009 : 65-66).

Tanjidor diambil dari kata tangedor bahasa Portugis yang artinya alat-alat musik berdawai (Ensiklopedi Nasional Indonesia, 2003:82). Tanjidor adalah jenis kesenian tradisional yang tumbuh dan berkembang di daerah Betawi (Jakarta) dan sekitarnya, termasuk dalam hal ini di Kabupaten Tangerang Provinsi Banten.

Perkembangan kesenian tanji atau tanjidor menjadi kesenian modern yaitu menjadi kesenian tanjidor (tanji dan bodor), kesenian jipeng (tanji dan topeng), kesenian jikes (tanji dan orkes).

\section{b. Sanggar Tanjidor Jikes Al-Jabar}

Namanya Sanggar Jikes Al-Jabar (Tanji Orkes Al-Jabar) yang dipimpin oleh Jaip Al-Jabar beralamat di Kampung Nanggul, Desa Sukasari, Kecamatan Rajeg, Kabupaten Tangerang, Provinsi Banten. Sanggar ini berdiri di atas tanah dengan luas kurang lebih $400 \mathrm{~m}^{2}$ milik Pak Jaip Jabar, namun tanah ini belum bersertifikat. Rencananya tanah milik Pak Jaip ini akan diwakafkan untuk kepentingan Sanggar Seni Jikes Al-Jabar.

Di dalam bangunan sanggar yang bentuk dan bahannya masih sederhana, dan merupakan bangunan semi permanen itu terdapat peralatan kesenian tanjidor atau jikes milik kelompok pimpinan Pak Jaip. Menurut penuturan Pak Jaip, semua peralatan ini dibeli dengan uangnya. Tidak satu pun peralatan ini berasal dari pemberian atau sumbangan baik dari perorangan maupun lembaga.
Pa Jaip Jabar menekuni kesenian tanjidor sejak dulu. Beliau sebagai penerus keturunan dari orang tua termasuk penerus kakeknya. Kesenian ini menurut penuturannya sudah ada dan tumbuh kembang pada zaman penjajahan Belanda. Secara kasat mata dapat dilihat bahwa peralatan tanjidor berasal dari bangsa Eropa, yaitu Portugis.

Sanggar jikes atau tanji orkes milik Pak Jaip ini secara formal berdiri sekitar tahun 1990. Pak Jaip memiliki darah seni tanjidor meneruskan langkah orang tuanya. Nama orang tua Pak Jaip adalah Haji Natsir. Haji Natsir, tokoh tanjidor pada masanya sebelum diteruskan oleh Pak Jaip Jabar.

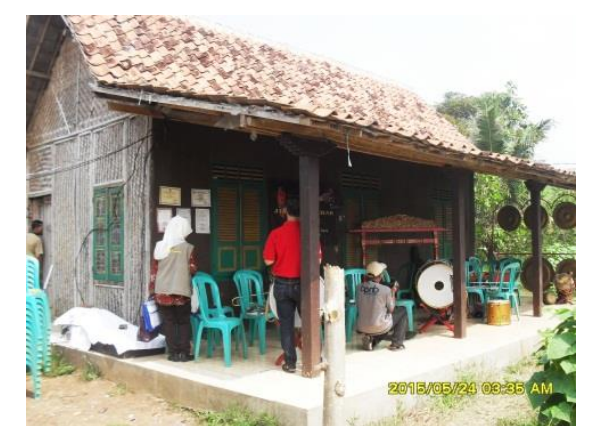

Gambar 7. Sanggar Tanjidor Jikes Jaip AlJabar

Sumber: Dok. BPNB Bandung 2015

Sanggar Jikes Jaip Al-Jabar memiliki kepengurusan sebagai berikut: Ketua - Jaip Jabar, Sekretaris - Rico, Bendahara - Ibu Enah. Adapun anggotanya Jarhardian sebagai pemain terompet, Romi pemain klarinet, Bira pemain klarinet/saxopon, Jamal pemain tambur, Dadang pemain tenor, Mardo pemain trombon, Irvan pemain simbal, Risno pemain drum/tambur kecil, Ibu Aat sebagai ronggeng, Sara pemain gendang, Otong penabuh gong, Ijar pemain biola Sunda, Juned pemain tehyan, dan Ega pemain terompet.

Pak Jaip menguasai kesenian tanjidor ini karena sering mendengar dan terlibat langsung bersama kakeknya tahun 1975. Oleh karena keseringan mendengar lagu yang dibawakan dalam kesenian ini, akhirnya beliau bisa menghapal baik syair- 
syair lagunya maupun semua peralatan musiknya. Misalnya lagu Mars Jalan didendangkan ketika ada arak-arakan jalan kaki. Irama Mars dimainkan untuk dansa para bule dan nona Belanda ketika diadakan pesta di gedung pemerintahan penjajah Belanda. Mars Penganten didendangkan ketika menyambut pengantin laki-laki ke pihak pengantin perempuan, dan lagu lainnya seperti Mars Grip dan Mars Siam.

Menurut Pak Jaip beberapa tahun kemudian diadakan kolaborasi peralatan musik dari luar seperti klarinet, terompet, tenor, bass, trombon, tambur besar, dan simbal. Selanjutnya menurut peralatan hasil kolaborasi digabung dengan peralatan dari daerah seperti gendang, gong, dan alat gesek. Alat gesek yang digunakan pada tanjidor setiap daerah ternyata berbeda, di wilayah Betawi menggunakan tehyan, Melayu menggunakan biola, dan di Sunda menggunakan rebab. Secara langsung keberadaan alat gesek ini merupakan ciri khas tanjidor dari daerah tempat berkembang kesenian tradisional ini.

Pada perkembangan selanjutnya tanjidor ini ada yang berubah menjadi jipeng (tanji topeng). Jipeng atau tanji topeng dalam penyajiannya tidak hanya menampilkan musik namun disertai seorang sinden sebagai vokalis, juga dalam alur pertunjukannya dilengkapi dengan sebuah drama atau cerita. Hal inilah yang mengundang masyarakat lebih berminat dan ingin mengetahui alur cerita di dalamnya.

Kesenian jipeng ini biasa main mulai sekitar pukul 07.00-09.00 pagi sesuai dengan jadwal acara si empunya hajat. Pukul 09.00 pagi biasanya pengantin diarak kampung dan ketika besan atau pihak keluarga besar laki-laki akan pulang maka akan diiringi dengan lagu Jepret Payung.

Kini kesenian tanjidor sesuai dengan namanya tanji bodor sudah dilengkapi dengan pemain dan cerita bodor; cerita lucu yang mengundang penonton untuk tertawa. Perkembangan selanjutnya munculah jinong (tanji lenong) dan jibus atau tanjibus (tanji gambus). Biasanya permainannya kalau tanji dipagelarkan siang hari dan malam harinya dipagelarkan irama gambus.

Para pemain tanjidor di sanggar milik Pak Jaip Jabar ini didominasi para pemuda, mereka masih kerabat dekat Pak Jaip sebagai keponakan. Menurut Pak Jaip dahulu pernah dilakukan perekrutan kader pemain tanjidor melalui karang taruna di lingkungannya. Ada pula keluarga yang datang untuk belajar. Mulanya mereka belajar memukul dan memainkan alat musik sambil memerhatikan kebiasaan bermain. Lama kelamaan paham dan bisa memainkan alat musik tanjidor sehingga dapat bergabung di sanggar Pak Jaip Jabar. Masyarakat yang datang ke Sanggar Jikes Al-Jabar yang ingin belajar akan disambut hangat oleh Pak Jaip. Kepadanya dipinjamkan alat seni untuk dimainkan sebagai alat peraga latihan. Setelah bisa memainkannya, kemudian oleh Pak Jaip Jabar diberikan notasinya, sehingga orang tersebut lama-kelamaan jadi pandai memainkan alat seni tanjidor.

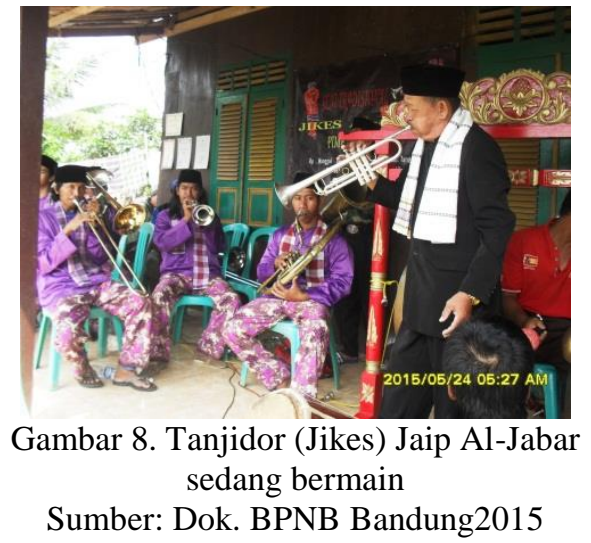

Bagi para pemain tanjidor yang bergabung ke dalam Jikes Al-Jabar menjadikan pekerjaan ini sebagai mata pencaharian pokok, karena hasil dari setiap manggung cukup untuk menghidupi keluarga. Hal ini, menurut Pak Jaip disebabkan banyak lembaga atau perorangan yang mengundang grup kesenian tanjidor untuk manggung. Namun Pak Jaip mengakui bahwa para 
pemain ini tidak setiap hari bisa manggung sehingga mereka adakalanya memiliki pekerjaan sampingan sebagai petani, tukang ojek, pedagang, pegawai honorer, dan sebagainya.

$$
\text { Masyarakat Desa Nanggul }
$$

Kabupaten Tangerang dahulu berasumsi masa depan pemain tanjidor tidak menjanjikan. Mereka bersumpah janganlah anak gadisnya dijodohkan dengan panjah (pemain musik), karena masa depannya akan suram. Namun sekarang, mereka tidak keberatan lagi untuk menikahkan anak gadisnya dengan panjah karena penghasilannya dapat diandalkan.

Menurut Pak Jaip Jabar kalau dirataratakan penghasilan para pemain setiap bulannya bisa mencapai Rp 4.000.000,Namun demikian, tidak dapat dikatakan bahwa setiap bulannya tetap, karena kadang mendapatkan hasil besar terkadang mendapat hasil yang kecil. Sekali manggung, setelah mendapatkan upah, kemudian dipotong dengan biaya pengeluaran ongkos mobil dan buat uang kas $20 \%$, sisanya dibagikan sesuai kelaskelas para pemain. Kelas tertinggi mendapatkan honor $\mathrm{Rp} 300.000,-$, kelas kedua mendapatkan honor Rp 200.000,-, dan kelas ketiga mendapatkan honor $\mathrm{Rp}$ 100.000,-.

Setelah berkembangnya tanjidor menjadi beberapa jenis kesenian, jumlah pemainnya juga masing-masing berbeda disesuaikan dengan kebutuhan kesenian tersebut misalnya pemain tanjidor berjumlah 12 orang, pemain tanji berjumlah 8 orang, pemain jikes atau tanji orkes berjumlah 12 orang, tanjidor modern pemainnya berjumlah 18 orang, dan pemain jipeng atau tanji topeng berjumlah 25 orang.

Cerita atau lakon yang terdapat dalam permainan jipeng (tanji topeng) berasal dari cerita klasik babad dan roman. Menurut Pak Jaip grup kesenian tanjidor yang dipimpinnya tidak menggunakan perlengkapan seperti sesajian dan seperangkat kemenyan. Namun jika ada tuan rumah atau yang empunya hajat menggunakan peralatan seperti itu tidak menjadi masalah. Hanya perlengkapan tersebut bukan menjadi salah satu kelengkapan yang selalu ada atau diharuskan dalam kesenian tanjidor yang dipimpinnya.

Para pemain tanjidor biasanya mengenakan seragam. Pemakaian seragam selain menunjukkan formal juga akan terlihat lebih ceria dan bergairah, imbasnya akan memikat hati para penonton. Jenisjenis pakaian dalam tanjidor adalah sebagai berikut:

1. Pakaian Koko atau Sadariah

Berupa atasan polos, bawah mengenakan batik, serta mengenakan peci atau kopiah. Selain itu pakaian lainnya adalah pakaian serba hitam mirip pakaian pangsi yang biasa digunakan masyarakat Sunda ditambah dengan peci (kopiah).

2. Baju Demang

Pakaian yang bentuknya baju koko dan celana terus diselendangkan sarung, pada bagian sakunya atau kantongnya ada kuku macan.

3. Baju Abdon

Pakaian ini bentuknya bagian atas berupa baju jas abang pakai blangkon.

Jikes Al-Jabar pimpinan Pak Jaip sudah malang melintang dalam dunia kesenian tradisional tanji orkes. Oleh karena itu grup ini banyak manggung dan dikenal oleh masyarakat kesenian di Kabupaten Tangerang, khususnya dan daerah DKI Jakarta pada umumnya. Banyak penghargaan yang diberikan kepada Sanggar Jikes Al-Jabar ini di antaranya:

1. Penghargaan dari Pemerintah Kabupaten Tangerang, Dinas Pemuda Olah Raga Kebudayaan dan Pariwisata, sebagai sanggar yang berperan aktif dalam Pelestarian Seni Budaya Daerah di Kabupaten Tangerang. Tertanggal Tangerang, 29 Desember 2009.

2. Penghargaan dari Departemen Kebudayaan dan Pariwisata, Asisten Deputi Urusan Kesenian, Deputi 
Bidang Seni dan Film, sebagai pemusik pada Festival Tari Indonesia. Tertanggal Jakarta, 12 Agustus 2005.

3. Penghargaan dari Dinas Kebudayaan DKI Jakarta, untuk peran sertanya dalam mengembangkan Seni Budaya di DKI Jakarta sebagai Nominasi 1, dalam kegiatan Festival Musik Tanjidor dan Ondel-ondel Betawi. Tertanggal Jakarta, 16 Januari 2000.

4. Penghargaan dari Presiden Direktur Setia Tour \& Travel atas partisipasinya dalam acara Festival Kue Bulan di Mega Mall Pluit. Tertanggal Jakarta, 25 September 1999.

5. Penghargaan dari pemerintah Provinsi Banten, Dinas Kebudayaan dan Pariwisata atas peran sertanya dalam workshop Penguatan Lembaga Kesenian. Tertanggal Serang, 7 Mei 2009.

Seni Jikes (tanji orkes) Al-jabar ini sering manggung disewa perorangan yang akan melakukan sebuah hajat atau pesta, juga sering disewa oleh lembaga-lembaga seperti Dinas Kebudayaan DKI Jakarta, Lembaga Kebudayaan Betawi (LKB), Forum Rembug Betawi (FBR), TVRI, Net TV, dan Kompas TV.

\section{SANGGAR TOPENG BLANTEK PANGKER a. Topeng Blantek}

Nama blantek berasal dari bunyi beng beng tlek yaitu bunyi alat musik yang diperdengarkan pada kesenian ini. Versi lainnya mengatakan bahwa nama blantek ini berasal dari kata blenkteks yang artinya pertunjukan permainan drama atau lakon yang tidak menggunakan teks. Para pemain spontan mengeluarkan kata-kata tidak berdasarkan teks skenario yang biasa disiapkan pada tampilan-tampilan drama atau cerita kesenian lainnya.

Pertunjukan topeng blantek
merupakan sebuah tontonan yang
sederhana, tanpa dekor. Teknik
bermainnya juga bersahaja, sebagaimana
tampak pada rombongan-rombongan
blantek yang terdapat di beberapa, tempat
seperti Cijantung pimpinan Nasir Boyo, di

Ciseeng pimpinan Saiman, di Cilodong pimpinan Saaman, dan di Bojong Gede pimpinan Pilih. Dari beberapa segi tampak ada persamaan dengan topeng Betawi, ada juga yang mirip lenong. Sebagaimana umumnya teater rakyat, ciri utama blantek adalah lagu, akrab dengan penonton di sekelilingnya dan tanpa formalitas, tanpa memiliki disiplin waktu. Tontonan ini merupakan percampuran antara tari lepas, nyanyian, guyonan, penampilan lakon dan kadang-kadang ada juga sulapannya seperti yang dilakukan oleh rombongan blantek dari Ciseeng pimpinan Saiman ${ }^{4}$.

Icon atau ciri khas dari kesenian topeng blantek adalah adanya sundung tiga yang ditengah-tengahnya terdapat obor sebagai penerang. Sundung tiga ini merupakan tanggungan terbuat dari bambu yang dihubungkan dengan sebatang bambu untuk diletakkan pada pundak ketika membawanya atau menanggung. Biasanya sundung ini digunakan untuk mengangkut barang yang bentuknya panjang, namun ketika bermain sundung ini digunakan untuk menyimpan pakaian atau kostum. Dan para pemain mulai bermain di depan sundung tersebut.

Topeng blantek memang unik, keunikannya terlihat pada penampilannya yang sangat sederhana. Oleh karena itu, kesenian tradisional ini dikatakan sebagai kesenian tradisional kelas bawah. Kesederhanaannya dapat terlihat dari arena lapangan yang seadanya, tidak ada lampu penerang, tidak ada bangku untuk duduk baik penonton maupun pemain. Namun diakui oleh seniman kesenian ini, Marhasan bahwa keunikan ini membuatnya leluasa untuk berimajinasi. Kebebasan untuk berkreasi dan menumpahkan ide-ide dapat dimanfaatkan seluasluasnya sehingga apa yang ingin disampaikan kepada penonton berupa pesan-pesan dengan mudahnya dapat dituangkan.

\footnotetext{
${ }^{4}$ (http://beta-widijakarta. blogspot.com/2010/ 05/topeng-blantek.htmldiakses tangga 13 Agustus 2015, pukul 11.24 WIB).
} 
Arena bermain kesenian Tradisional topeng blantek ini di lapangan yang dulu jarang ada lampu penerang sehingga menggunakan obor. Namun saat ini ketika banyak lampu penerang keberadaan obor tetap dipertahankan. Tiga buah sundung diletakkan membentuk setengah lingkaran ke depan, bagian depan dijadikan arena pertunjukan, sementara bagian belakang sundung dijadikan tempat berkumpulnya para pemain yang menunggu giliran untuk bermain.

\section{b. Sanggar Topeng Blantek Pangker}

Sanggar Pangker Grup didirikan pada tanggal 22 Agustus 1987 oleh Marhasan. Nama "pangker" berasal dari singkatan (akronim) nama jalan dan nama tempat sekretariat sanggar ini, yaitu kepanjangan dari Pangkalan Keramat. Marhasan menjadi ketua sanggar tersebut. Sanggar ini beralamat di Jalan Pangkalan Keramat RT 06 RW 01, Kelurahan Semanan, Kecamatan Kalideres, Jakarta Barat.

Sanggar Pangker memiliki kepengurusan sebagai berikut: Ketua Marhasan, Wakil Ketua -

Muksin, Sekretaris - Sulaeman Yusuf, Bendahara - Amsori (Geco), Humas - Robani. Adapun anggotanya adalah Murad sebagai pemain gambang, Muksin sebagai aktor dan pemain, Bule sebagai pemain kenong/kromong, Husaeni sebagai pemain tehyan, Romih sebagai pemain gong, Dewi sebagai pemain, Heni Otis sebagai pemain, Muhidin sebagai pemain, Didi sebagai pemain, Rojak sebagai pemain gendang, Mamat sebagai pemain, Agus sebagai pemain, Muhasan sebagai pemain, dan Muhammad Dori sebagai pemain kecrek.

Menurut penuturan ketua Sanggar Pangker, Marhasan bahwa jumlah anggota yang aktif kurang lebih 15 orang sedangkan yang tidak aktif mencapai 35 orang, namun anggota yang tidak aktif sewaktu-waktu siap dipanggil jika dibutuhkan untuk memperkuat kesenian tersebut. Bisa dikatakan bahwa pemain yang tidak aktif posisinya sebagai pemain cadangan yang siap diterjunkan ke arena panggung seandainya grup membutuhkannya. Pemain cadangan mempunyai kemampuan sesuai bidangnya yang sudah teruji namun posisi mereka berada dalam pemain cadangan.

Menurut penuturan ketua Sanggar Pangker, Marhasan, regenerasi topeng blantek ini tidak dipaksakan baik kepada orang lain maupun kepada keluarganya sendiri. Diakuinya bahwa kepiawaian sebagai seniman topeng blantek bukan turunan dari orang tuanya, namun karena ketekunannya belajar kepada seniman senior, sehingga jadi seperti sekarang ini. Beliau pun tidak memaksakan kepada putra-putrinya untuk bergelut meneruskan profesi sebagai seniman topeng blantek. Mau ikutan silakan tidak pun tidak apaapa. Pertimbangannya antara lain bahwa pemaksaan karier untuk bergabung dengan seniman topeng blantek kepada orang lain atau kepada anaknya akan merusak masa depan seni budaya ini, juga masa depan pelaku. Oleh karena tidak baik sesuatu dilakukan dengan unsur pemaksaan, tapi diharapkan adanya keikhlasan dan kesadaran sendiri dari calon pemain, sehingga siap menerima kondisi apa pun yang akan diterima oleh seorang seniman tradisional. Hal ini disampaikannya karena ada kalanya harus kehilangan Sang Istri yang dicintai karena masalah ekonomi. Menurutnya sampai sekarang penghasilan seniman topeng blantek belum bisa diharapkan menjadi mata pencarian pokok yang dapat memenuhi kebutuhan hidup keluarga.

Para seniman di Sanggar Pangker ini sebagian besar menjadikan mata pencaharian sebagai seniman topeng blantek sebagai sampingan, dan biasanya yang dijadikan sebagai mata pencaharian pokok adalah sebagai tukang ojek, pemulung, wirausaha, pedagang, dan sebagainya.

Menurut Marhasan selama ini sebagai seniman topeng blantek harus siap mandiri untuk menghidupi seni budaya yang digelutinya, karena selain kurangnya 
peminat masyarakat yang mengundang manggung juga kurangnya perhatian dari berbagai pihak terutama dukungan materi.

Panggilan manggung masih sangat kurang dirasakan oleh para pemain topeng blantek di Sanggar Pangker ini. Jika ada undangan, upah sewa atau kontrak kerja ini cukup bervariasi, undangan pada eventevent, seperti manggung di Kampung Budaya Betawi mendapat honor kurang lebih Rp 5.000.000,-, pada acara-acara lainnya seperti pernikahan, ulang tahun, dan lain-lain mendapatkan upah tampil antara Rp 2.000.000,- Rp 3.000.000,-. Dari upah kontrak ini kemudian dibagikan langsung kepada para pemain dengan rincian sebagai berikut: para pemain biasanya mendapatkan honor berkisar $\mathrm{Rp}$ 200.000,- sedangkan pemusik berkisar Rp150.000,- sampai Rp 200.000,-.

Di sanggar Pangker ini biasa dilakukan latihan agar setiap pemain selalu siap manggung, jadwal latihan dalam seminggu satu kali, yaitu pada malam Sabtu. Biasanya yang dilatihkan kepada para pemain itu adalah dasar-dasar seni topeng blantek, dan yang menjadi pelatihnya adalah Muhasan. Biasanya mereka berlatih untuk mempersiapkan manggung dilakukan dua (2) hari sebelum hari $\mathrm{H}$.

Grup kesenian Topeng Blantek Sanggar Pangker sudah memiliki peralatan yang lengkap, namun sanggar ini belum memiliki tempat permanen untuk latihan. Selama ini tempat latihan dilakukan di luar, di lapangan terbuka, atau di pinggir kali. Adakalanya berlatih di pinggir rumah bendahara Sanggar Pangker karena sampai sekarang belum memiliki gedung khusus sanggar.

Lakon cerita yang biasa ditampilkan oleh Grup Topeng Blantek Sanggar Pangker ini adalah Anak Betawi Naik Daun, Mat Capeng Anak dari Pak Lurah, Pemilihan Demang, juragan Jeber, Pintarpintar Bodoh, Antara Si Miskin dan Si Kaya.

Menurut Marhasan sampai sekarang dirinya sudah berhasil mengembangkan kesenian topeng blantek yaitu dengan berdirinya Sanggar Si Jeber di Cengkareng yang didirikan oleh salah seorang binaannya yang bernama Didid. Sampai sekarang beliau masih memberikan masukan-masukan terhadap kelangsungan sanggar yang baru berdiri ini.

\section{c. Sanggar Topeng Blantek Fajar Ibnu Sena.}

Sanggar Topeng Blantek Fajar Ibnu Sena didirikan oleh Natsir Mufid pada tanggal 5 Agustus 1983. Sanggar ini berkedudukan di Gg. H. Syatiri nomor 88 RT 02 RW 03, Kelurahan Ulu Jami, Kecamatan Pesanggrahan, Jakarta Selatan.

Istilah Ibnu Sena yang dijadikan nama sanggar ini diambil dari nama peran tokoh Islam dunia yang sangat populer dengan kepintarannya pada bidang ilmu kedokteran yaitu Dr. Ibnu Sena.

Pak Natsir Mufid yang kini tahun 2015 berusia 53 tahun, selain sebagai pendiri sanggar juga menjadi ketua sanggar sekaligus ketua Topeng Blantek Fajar Ibnu Sena. Beliau memiliki seorang istri bernama Suroyah, berusia 48 yang kini sudah cerai. Dari pernikahannya ini dikarunia tiga putra dan seorang putri, yaitu:

1. Fajar Ibnu Sena berusia 27 tahun

2. Ratih Nurul Sena berusia 26 tahun

3. Hendra Setiawan berusia 25 tahun

4. Heri Saputra berusia 24 tahun

Dua anak yang terakhir ini, yaitu Hendra Setiawan dan Heri Saputra mengikuti jejak ayahnya menggeluti kesenian topeng blantek. Kepengurusan Sanggar Topeng Blantek Fajar Ibnu Sena adalah: Ketua - Natsir Mufid, Wakil Ketua - Fauji, Sekretaris - Abdul Aziz, Bendahara - Hendra Setiawan, Humas - Agus Rianto. Adapun anggotanya Tihanah, Siti Rohayah, dan Fauziah sebagai pemainbiasanya dengan peran ibu, Firda sebagai pemain dengan peran anak, Hasya sebagai pemain dengan peran pembantu, Winda sebagai pemain dengan peran anak, Sabrawi sebagai pemain dengan peran jawara, Abdul Azim sebagai pemain dengan peran pembantu, Nurhasan sebagai 
pemain dengan peran juragan, Sukmajaya sebagai pemain dengan peran centeng, Nashud sebagai pemain dengan peran jawara, Abdullah sebagai pemain dengan peran pembantu, Rodit sebagai pemain dengan peran anak, Hendra sebagai pemain dengan peran anak, Agus Salim sebagai pemain dengan peran pendekar, Komarudin sebagai pemain dengan peran pendekar, Subrata sebagai pemain dengan peran perampok, Oking sebagai pemain dengan peran pembantu, Supriyanto sebagai pemain dengan peran pembantu, Jamal sebagai pemain dengan peran juragan, Jamian sebagai pemain dengan peran ustadz, Muamilidih sebagai pemain dengan peran guru silat, Mamat sebagai pemain musik tehyan, Endang sebagai pemain musik gendang, Ojih sebagai pemain musik gambang, Loli sebagai pemain musik kenong, Agus Buduy sebagai pemain musik kecrek, dan Sudrajat sebagai pemain musik gong.

Menurut penuturan ketua sanggar, Natsir Mufid jumlah pemusik Topeng Blantek Fajar Ibnu Sena ada 10 orang dan pemain peran berjumlah 15 orang. Duapuluh lima (25) orang ini sebagai pemain yang masih aktif, sementara itu pemain yang tidak aktif jumlahnya bisa ratusan orang. Pemain tidak aktif ini biasanya keluar masuk atau mereka berperan sebagai pemain cadangan, manakala tim membutuhkan mereka, mereka akan selalu siap tampil. Kemudian personel penari seorang, pesilat 3 orang, jantuk seorang, dan bodor seorang.

Kisah atau cerita drama yang biasa dipertunjukkan grup topeng blantek ini di antaranya adalah Jampang Mayangsari, Jampang Sarba, Tiga Buronan, Perkawinan, dan Jantuk Jadi Dukun. Tampilan yang selalu dalam Topeng Blantek Fajar Ibnu Sena adalah tarian, pencak silat, pengiring, pengantin, dan peran Si Jantuk yang mengenakan topeng berperan sebagai pelawak.

Dalam keseharian berlatih baik latihan biasa maupun latihan akan manggung yang menjadi pelatih adalah
Natsir Mufid sebagai pelatih utama sementara yang menjadi pelatih pembantu adalah Abdul Aziz dan Ahmad Fauzi. Sementara itu yang menjadi pelatih pencak silat adalah Agus Salim dan yang menjadi pelatih tari adalah Tihanah.

Para pemain biasanya berlatih dalam satu minggu hanya sekali yakni pada hari Minggu. Waktu latihan dari pukul 13.0018.00 WIB atau dari pukul 13.00-22.00 WIB. Saat berlatih biasanya digunakan pula untuk berdiskusi antarpemain topeng blantek ini. Jika ada undangan untuk manggung maka dilakukan latihan untuk mempersiapkannya, biasanya mereka berlatih tiga (3) hari sebelum hari H-nya.

Untuk regenerasi pemain pernah diadakan perekrutan pemain baru secara terbuka misalnya bekerjasama dengan organisasi pemuda karang taruna RW setempat. Hasilnya para pemain yang bergabung sekarang ini di antaranya adalah berasal dari aktivis karang taruna. Ketika pertama kali diumumkan oleh karang taruna banyak sekali pemuda pemudi dan remaja yang bergabung untuk berlatih topeng blantek, namun dalam perjalanan waktu akhirnya kebanyakan mereka berguguran keluar. Personal yang tetap bergabung biasanya mereka yang memiliki darah seni dan bakat seni dari orang tuanya.

Menurut penuturan pemimpin Sanggar Topeng Blantek Fajar Ibnu Sena, sampai sekarang belum ada bantuan dari pihak pemerintah. Hal ini dapat diterima karena untuk mendapatkan bantuan seperti bantuan sosial (bansos) yang berkaitan dengan sanggar harus memiliki persyaratan yang lengkap, seperti kepemilikan sekretariat sanggar yang dikukuhkan dengan sertifikat atas nama sanggar, harus adanya kegiatan rutin dari sanggar seperti pelatihan rutin di sanggar, pembinaan generasi muda di sanggar, pertunjukan rutin di sanggar untuk masyarakat sekitar, Hal inilah yang belum dikantongi oleh Sanggar Topeng Blantek Fajar Ibnu Sena, mereka belum memiliki sanggar tersendiri dengan sertifikat atas nama sanggar. Untuk 
sementara, sekarang ini mereka berdiskusi atau berkumpul di rumah ketua, Natsir Mufid.

Menurut Natsir Mufid di antara bulan Juni-Agustus ini ada dua pentas, ini membuktikan bahwa masyarakat yang memanfaatkan topeng blantek untuk manggung pada acara-acara tertentu masih sangat minim. Sekali manggung upah yang diterima bervariasi mulai dari $\mathrm{Rp}$ 4.000.000,- sampai Rp 6.000.000,-. Upah manggung di Kampung Budaya Betawi Rp $6.000 .000,-$, , sedangkan ditempat lainnya kurang dari itu. Selesai manggung biasanya honor langsung dibagikan kepada para pemain, honor tertinggi Rp150.000,dan yang lainnya berkisar antara Rp50.000,- sampai Rp100.000,-.

Minimnya pendapatan dari profesi pemain topeng blantek, menyebabkan profesi ini bukan dijadikan sebagai mata pencaharian pokok tapi dijadikan sebagai mata pencaharian sampingan. Mata pencaharian pokok mereka adalah sebagai satpam, pedagang pakaian, guru, penggosok batu akik, ojek, dan sopir taksi.

Penghargaan yang pernah diberikan kepada sanggar ini adalah penghargaan seni sebagai Seniman 2007 dari Suku Dinas (Sudin) Budaya Jakarta Selatan DKI Jakarta.

\section{Peranan Sanggar}

Peranan sanggar dalam kesenian tradisional khususnya kesenian yang menjadi objek penelitian ini yaitu kesenian topeng Betawi, topeng blantek, dan kesenian tanjidor dapat dikategorikan sebagai berikut:

1) Sanggar sebagai wadah atau tempat bernaung sejumlah seni budaya.

2) Sanggar sebagai media edukasi baik itu pendidikan dan latihan.

3) Sanggar sebagai media hiburan bagi masyarakat sekitar dan peminat seni.

4) Sanggar sebagai tempat mengatur strategi seputar seni yang digeluti.

5) Sanggar sebagai tempat berkumpul, bersilaturahmi, dan berdiskusi dalam rangka mempererat persaudaraan.
Sanggar-sanggar yang dijadikan objek penelitian ini, sebenarnya masih jauh untuk dikatakan sebagai sanggar yang lengkap dan memenuhi syarat. Pada umumnya sanggar yang mereka buat lebih tepat hanyalah sebagai sekretariat atau wadah penampungan seni budaya yang mereka geluti. Keempat sanggar ini masih belum memiliki sertifikat yang mengatasnamakan sanggar atau yayasan, kecuali Sanggar Topeng Betawi Cinta Damai. Selain itu belum memiliki jadwal latihan yang kontinu dengan frekuensi yang padat, juga belum ada kegiatankegiatan yang menunjang sanggar tersebut, misalnya di sanggar belum ada pertunjukan rutin untuk hiburan masyarakat setempat. Di sanggar belum ada kegiatan menambah wawasan dan pengetahuan seni seperti seminar, workshop, diklat, pameran dan sebagainya. Namun demikian kehadiran sanggar yang mereka miliki sudah merupakan upaya mandiri mereka untuk memperlihatkan, mempertahankan, menjaga, melestarikan, dan melindungi kesenian tradisional yang mereka kuasai sebagai warisan dari leluhurnya.

Peranan sanggar dalam meningkatkan kualitas kesenian tradisional khususnya kesenian tradisional yang terdapat di wilayah Jabotabek (Jakarta Bogor dan Bekasi) yang meliputi sanggar kesenian topeng Betawi, topeng blantek, dan tanjidor cukup terlihat.

Sanggar yang memiliki perlengkapan yang relatif lebih baik mulai dari perlengkapan musik, gedung tempat latihan, dan sumber daya manusia akan terlihat relatif lebih mapan dan banyak undangan untuk manggung seperti pada Sanggar Jikes Jaip Al-Jabar dan Sanggar Topeng Betawi Cinta Damai. Sanggar Jikes Jaip Al-Jabar yang menekuni bidang kesenian tanjidor sudah memiliki gedung sanggar dan perlengkapan yang tersimpan di dalamnya. Gedung dan halaman yang luasnya kurang lebih 400 meter persegi ini menjadi sekretariat tempat berlatih, diskusi, dan tempat belajar bagi yang 
menginginkannya. Para pemainnya menjadikan profesi ini sebagai mata pencaharian utama karena tiap bulan dirata-ratakan pendapatan mereka kurang lebih Rp 4.000.000,-. Hal ini meningkatkan status sosial masyarakat yang tadinya menganggap rendah menjadi seniman sekarang tidak lagi. Dulunya orang tua akan menasihati putri tercintanya untuk berhubungan atau menikah dengan pemain tanjidor, namun sekarang mereka tidak keberatan.

Sanggar Cinta Damai pimpinan Amin memiliki gedung yang berdampingan dengan rumahnya. Di tempat inilah para pemain berlatih rutin, baik untuk meningkatkan kualitas permainan maupun untuk menyiapkan tim ketika akan manggung. Begitu pula Sanggar Topeng Betawi Setia Warga pimpinan Idi yang masih keturunan seniman senior Bokir memiliki gedung yang merupakan bagian dari rumahnya. Di tempat itulah kadang dijadikan tempat untuk berlatih. Sementara itu sanggar lainnya seperti Sanggar Topeng Blantek Pangker dan Sanggar Topeng Blantek Fajar Ibnu Sena belum memiliki gedung baik untuk menyimpan perlengkapan gamelan maupun sebagai tempat untuk berlatih. Kedua sanggar ini jika akan manggung atau melatih timnya, harus menuju tempat lain. Padahal Topeng Blantek Pangker dan Fajar Ibnu Sena diakuinya sebagai grup asli yang menguasai seni topeng blantek di Betawi.

\section{PENUTUP}

Kesenian tradisional sebagai hasil karya, cipta, dan karsa para pendahulu yang diturunkan kepada generasi penerus dengan cara belajar. Kesenian tradisional merupakan kristalisasi kreativitas para pendahulu yang menyalurkan hobi, bakat dan ingin membuat senang orang lain. Mulanya kesenian tradisional bertujuan untuk hiburan, pendidikan, dan kebutuhan sakral terutama pada upacara-upacara.

Dalam perkembangan selanjutnya di era millenium yang serba canggih, keberadaan kesenian tradisional semakin tersisihkan, beberapa di antaranya ada yang punah, mati enggan hidup tak mau, namun ada pula yang eksis dan sejajar dengan kesenian modern lainnya seperti kesenian jaipong, angklung, tari Bali, dan sebagainya.

Berbagai cara dilakukan untuk menyelamatkan kesenian tradisional dari kepunahan. Hal ini dilakukan oleh berbagai elemen selain pemerintah seperti seniman, LSM, dan komponen lainnya. Salah satu upaya yang sudah dilakukan oleh seniman dalam rangka menyelamatkan dan menjaga kesenian tradisional agar tetap hidup adalah dikelola di dalam sanggar.

Selanjutnya di dalam sanggar pembinaan dan pelatihan para pemain terus dilakukan secara kontinuitas walapun dalam frekuensi yang masih minim dan terbatas, karena mereka berlatih sekadarnya dan hanya untuk mempersiapkan bila akan manggung. Namun eksistensi sanggar sangat kursial dan penting sebagai upaya penyelamatan kesenian tradisional seperti topeng Betawi, topeng blantek, dan tanjidor.

Kehadiran sanggar sangat menopang dan mendukung kemajuan seni budaya yang berada di dalamnya. Semakin lengkap dan memadai fasilitas di dalamnya, akan berdampak pada kelestarian seni budaya, kemajuan, dan kesejahteraan para pelaku seni tersebut. Namun disayangkan pada umumnya para pendukung seni tradisional yang menekuni dan bergelut di dalam kesenian tradisional tidak didukung faktor ekonomi yang memadai. Oleh karena itu perlu adanya campur tangan pihak lain termasuk pemerintah, pengusaha, pegiat dan pendukung kesenian ini untuk mengeluarkan bantuan terutama dana dan pembinaan.

\section{DAFTAR SUMBER}

1. Buku

Bachtiar, Wardi. 1997. 
Metode Penelitian Ilmu Dakwah. Pamulang Timur Ciputat: Logos Wacana Ilmu.

Ensiklopedi Nasional Indonesia, jilid 3 dan 16, 1989. Jakarta: Cipta Adi Pustaka.

Kahmad,Dadang. 2000.

Metode Penelitian Agama, Perspektif

Ilmu Perbandingan Agama. Bandung:

Pustaka Setia.

Lasmiyati. 2002.

Dinamika Kesenian Tanjidor dan Profil Sanggar Putera Mayangsari. Bandung : Mawar Putra Perdana.

Moleong, Lexy J. 1989.

Metodologi Penelitian Kualitatif.

Bandung : Remaja Karya.

Setiati, Eni. 2009

Ensiklopedi Jakarta, 5, Jakarta Tempo Dulu, Kini, dan Esok. Jakarta: Lentera Abadi.

\section{Internet}

Al-hazmi, Nursabila. "Peran Sang-gar Seni dalam Menunjang Kegiatan Bim-bingan Edukatif pada Pameran Benda Budaya Koleksi Museum-museum di Papua” diakses dari http://sabilaqueen.blogspot.com/2011/02/ peran-sanggar-seni-dalam-menun jang.htdml, tanggal 13 Agustus 2015 pukul 10.00 WIB.

https://id.wikipedia.org/ wiki/ Sanggar, diakses tanggal 13 Agustus 2015 pukul 10.10 WIB.

http://www.jakarta.go.id/web/encyclopedia/det ail/3343/Topeng-Betawi diakses tanggal 13 Agustus 2015, pukul 11.00 WIB.

http://Betawidijakarta. blogspot.com/2010/05/ topeng-blantek.html diakses tangga 13 Agustus 2015, pukul 11.24 WIB 